\title{
Lasten omat tubettajat maailmalla
}

Viisivuotias poikani katsoo mielellään lastenvideoita YouTubesta. Vanhemman kannalta harrastus aiheuttaa harmaita hiuksia, sillä YouTuben sisältöä ei pysty täysin ulkoapäin kontrolloimaan. Algoritmi valitsee ja suosittelee videoita pojalleni olettaen tietävänsä, mitä hän haluaa katsoa. Asetuksia voi toki säätää lapsiystävällisiksi, mutta kansainvälisellä tasolla voi vallita hyvin erilaisia käsityksiä siitä, mitä lapsiystävällisyys oikeastaan tarkoittaa. Toisaalta suositusten yllätyksellisyydessä on myös hyvät puolensa.

Hyvä puoli on, että poikani tietokoneelta kaikuu koko olohuoneeseen uskomaton kielten kirjo: espanjalaista animaatiosarjaa Pocoyota; thaimaalainen perhe, joka on animoinut haikaloja uimaan uima-altaaseensa tai turkkilaiset lapset leikkimässä, että heidän kotinsa lattialla on laavaa. Aasialaisia, pelimoottorilla rakennettuja psykedeelisiä Spiderman-tanssivideoita. Viisivuotiaalle englanti on vain yksi vieras kieli muiden joukossa, eikä kielimuuri ole esteenä hassuista trikeistä tai toisten lasten leikkimisestä nauttimiselle.

Hetken aikaa poikani suosikkikanava oli Vlad and Nikita. Vladislav ja Nikita ovat 6- ja 4-vuotiaat venäläiset veljekset, jotka vanhempiensa kanssa asuvat Miami Beachilla Floridassa. Videoissa he leikkivät äitinsä kanssa upeassa talossa - amerikkalaiseen tyyliin melkein kartanossa - ja testaavat leluja välillä hyvinkin mainoksenkaltaisissa olosuhteissa. Äiti on huoliteltu kuin huippumalli ja isä ilmeisesti ammattikuvaaja. Välillä leikit ovat suomalaisen mittapuun mukaan aika rajuja: ampumista ja ilkeiden kepposten tekemistä. Kanava onkin välillä ollut poistettuna YouTubesta, mutta on sittemmin tehnyt paluun hieman siistittynä ja uudella nimellä. "Kaksi poikaa ja äiti" - niin kuin minun poikani kanavaa nimittää - saavat viikoittaisille postauksilleen parhaimmillaan 350 miljoonaa katsomiskertaa per jakso.

Videopäiväkirjaa ja lelupromoamista yhdistävien kanavien ohella poikani pitää Let's Play -kanavista. Niissä saa seurata kun joku toinen pelaa mielenkiintoisia tietokonepelejä ja kommentoi niitä hauskalla tavalla. Videoista saa inspiraatiota kivojen pelien valintaan, ja jos pelaa samaa peliä joskus myös itse, saa hyviä vinkkejä tehtävien ratkomiseen. Ennen kaikkea videoista saa pelaamisen jakamisen kokemuksen.

Poikani tykkää katsoa venäläistä kommentaattoria kanavalla Igruli s papulei ("Pienet pelaa isukin kanssa"), jossa testataan erilaisia lapsille kiinnostavia pelejä. Isukki kommentoi pikkuoravaääneksi muunnetulla suloisella venäjällä vaikkapa miten "Krasnyi Šarik" (Punainen pallo) ratkaisee tasot ja pohtii omaa pyörivää menoaan. Poikani nauraa ääneen, omaksuu vinkit ja soveltaa niitä sitten itse Red Ball -peliä tabletilla pelatessaan. Pelikanavan ansiosta hän osaa tunnistaa eri kielten seasta jo venäjän, mutta ei sentään kommentoi omaa peliään venäjäksi - vielä. Sen sijaan "Oh my God" (ja jopa "What the f**k") huudahduksia kuuluu silloin tällöin. 
YouTuben kautta koko perheemme on tutustunut myös valloittavaan pelihahmoon nimeltä Chuchel. Kyseessä on tšekkiläisen Amanita Design -peliyhtiön ja suunnittelija Jaromir Plachýn luoma taiteellisesti korkeatasoinen lasten seikkailupeli. Aikuinen arvostaa sitä, että myös pelin äänimaailmaan on panostettu: vaihtoehtorockbändi DVA on jopa julkaissut peliä varten säveltämänsä musiikin studioalbuminaan. Monet pelin tasoista on rakennettu pastisseiksi tietokonepelien klassikoista, kuten Space Invaders tai Pacman. Parodian kohteena on myös Tetris - neuvostoliitolaisen koodarin Aleksei Pažitnovin vuonna 1984 luoma maailmanmenestys. Erityisesti poikani tykkää katsoa Chuchelia brittiläisen Ethan-pojan pelaamana. Ethan Gamer -kanavan vetäjä on 13-vuotias, sofistikoitunut nuori mies, joka pelaamisen väliin saattaa sisällyttää myös pianoharjoituksiaan - mikä teki poikaani erityisen suuren vaikutuksen.

Pojallani ja kaikilla muilla maailman tubettajia seuraavilla lapsilla on kokonaan oma kuplansa, joka sisältää kanavia, jotka eivät koskaan olisi tulleet minulle vastaan, jos en olisi äiti. Poikani tiesi jo kauan ennen minua, kuka on japanilais-amerikkalainen Ryan ja mikä on Ryan Toys Review. Se oli pyörinyt olohuoneessamme jo kuukausia, ennen kuin minulle selvisi, että Ryan on maailman eniten tienaava YouTube-tähti. Lasten voima kulttuurin kuluttajina on arvaamattoman suuri.

Lasten oma maailma ja heitä kiinnostavat asiat ansaitsisivat tulla laajemmin tutkituiksi eikä pelkästään tuomituiksi. Esimerkiksi kirjallisuudentutkimuksen näkökulmasta mielenkiintoinen kysymys on, minkälaisia vaikutuksia on sillä, että lapseni tottuu katsomaan tarinoita, joissa lineaarinen narratiivi ei enää olekaan selviö. YouTube- ja pelikulttuurin kautta lapset ympäri maailmat tottuvat absurdimpaan ja katkonaisempaan kerrontaan kuin mihin me vanhemmat olemme aikoinaan tottuneet. Erityisesti syklinen muoto on peleistä omaksuttu tapa kertoa ja rakentaa videoita: asiat toistuvat samanlaisena tai pienin variaatioin ilman varsinaista draaman kaarta. Hämähäkkimies tanssii saman tanssin auton katolla ensin sinisenä, sitten vihreänä ja lopuksi pinkkinä - minä koen tämän videon tylsänä ja joskus jopa hieman epämiellyttävänä. Lapsi saa siitä irti kuitenkin elämyksen, jota minä aikuisena en vielä täysin käsitä.

Minulle sanottiin pienenä, että älä katso telkkaria, menisit ulos. Minä puolestani yritän saada pojan pois tietokoneelta - katsoisit edes telkkaria äidin kanssa. Silti poikani tietokoneharrastuksen kautta olemme perheenä oppineet ja jakaneet paljon hienoja asioita: tutustuminen lapsiin ja lasten kulttuuriin eri maista on avartanut minunkin maailmaani huomattavasti - se on tekoälyn ja algoritmien suosituskuplan umpioimassa maailmassa korvaamattoman arvokasta. Lisäksi kielten ja kulttuurien moninaisuuden ymmärtäminen jo varhaislapsuudesta asti on tärkeä kokemus. Maailma on lähellä.

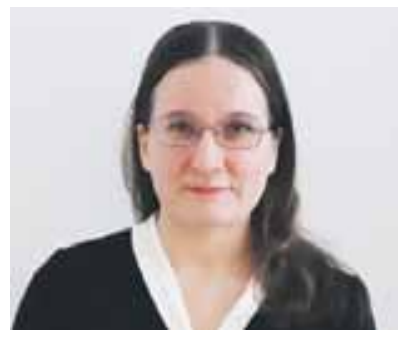

Ira Österberg

Kirjoittaja on venäläisen elokuvan ja nykykulttuurin post doc -tutkija sekä Idäntutkimuksen toimitussihteeri. 